\title{
Synthesis and mechanical properties of $\mathrm{Al}_{8} \mathrm{~B}_{4} \mathrm{C}_{7}$
}

\author{
Shinobu HASHIMOTO, Toshiya ISHIHARA, Koji INOUE, Sawao HONDA, Yuji IWAMOTO \\ and Shaowei ZHANG**
}

\author{
Department of Environmental and Materials Engineering, Nagoya Institute of Technology, \\ Gokiso-cho, Showa-ku, Nagoya-shi 466-8555 \\ ${ }^{*}$ Mie Industrial Research Institute, Department of Electrical Material Science, 5-5-45, Takachaya, Tsu-shi 514-0819 \\ ** Department of Engineering Materials, The University of Sheffield, Sir Robert Hadfield Building, Mappin Street, Sheffield S1 3JD, UK
}

\begin{abstract}
Aluminum boron carbide $\left(\mathrm{Al}_{8} \mathrm{~B}_{4} \mathrm{C}_{7}\right)$ was synthesized by heating a mixed powder consisting of $\mathrm{Al}: \mathrm{B}_{4} \mathrm{C}: \mathrm{C}=\mathbf{8 : 1 : 6}$ (molar ratio) at $1600^{\circ} \mathrm{C}$ for $1 \mathrm{~h}$. The synthesized $\mathrm{Al}_{8} \mathrm{~B}_{4} \mathrm{C}_{7}$ powder was ball milled for $24 \mathrm{~h}$ with alumina balls to prepare an $\mathrm{Al}_{8} \mathrm{~B}_{4} \mathrm{C}_{7}$ powder with under $40 \mu \mathrm{m}$ diameter. The fine $\mathrm{Al}_{8} \mathrm{~B}_{4} \mathrm{C}_{7}$ powder was then put into a carbon die, pressed, and sintered using PECS at $1650^{\circ} \mathrm{C}$ for $10 \mathrm{~min}$ under an applied pressure of $60 \mathrm{MPa}$, resulting in an $\mathrm{Al}_{8} \mathrm{~B}_{4} \mathrm{C}_{7}$ body with a relative density of $99.6 \%$. The bending strength, Vickers hardness, and fracture toughness of the dense $\mathrm{Al}_{8} \mathrm{~B}_{4} \mathrm{C}_{7}$ body were $500 \mathrm{MPa}, 15.2 \mathrm{GPa}$ and 2.3 $\mathrm{MPa} \cdot \mathrm{m}^{1 / 2}$, respectively. The bending strength of the dense $\mathrm{Al}_{8} \mathrm{~B}_{4} \mathrm{C}_{7}$ body increased during heating to $510 \mathrm{MPa}$ at $1000^{\circ} \mathrm{C}$, but decreased to $440 \mathrm{MPa}$ at $1200^{\circ} \mathrm{C}$.
\end{abstract}

(C)2009 The Ceramic Society of Japan. All rights reserved.

Key-words : $\mathrm{Al}_{8} \mathrm{~B}_{4} \mathrm{C}_{7}$, PECS (Pulsed Electric Current Sintering), Mechanical properties

[Received June 30, 2008; Accepted September 11, 2008]

\section{Introduction}

Thus far, several complex carbides in the Al-B-C ternary system, $\mathrm{Al}_{3} \mathrm{~B}_{48} \mathrm{C}_{2}, \mathrm{AlB}_{24} \mathrm{C}_{4}, \mathrm{Al}_{3} \mathrm{BC}$ and $\mathrm{Al}_{8} \mathrm{~B}_{4} \mathrm{C}_{7}$, have been reported. ${ }^{1)} \mathrm{Al}_{8} \mathrm{~B}_{4} \mathrm{C}_{7}$ was selected and fabricated by Inoue et al. ${ }^{2)}$ due to its ease of formation and high environmental stability (up to $1830^{\circ} \mathrm{C}$ ), and the crystallographic parameters were investigated in detail. Kharalamov et al. studied the electrical transport properties of $\mathrm{Al}_{8} \mathrm{~B}_{4} \mathrm{C}_{7}$, and found that it behaved as a semiconductor. ${ }^{3)}$ Wang and Yamaguchi synthesized pure $\mathrm{Al}_{8} \mathrm{~B}_{4} \mathrm{C}_{7}$ powder approximately ten years ago using a solid phase reaction, and fabricated a dense body using a PECS (pulsed electric current sintering) technique. They also investigated the oxidation behavior of both powdered and dense-body $\mathrm{Al}_{8} \mathrm{~B}_{4} \mathrm{C}_{7}$ in air at high temperatures. ${ }^{4)}$ In their investigation of $\mathrm{Al}_{8} \mathrm{~B}_{4} \mathrm{C}_{7}$ as a chemical reactant at high temperatures, Yamaguchi et al. showed that $\mathrm{Al}_{8} \mathrm{~B}_{4} \mathrm{C}_{7}$ works as an antioxidant in carbon-containing refractories, suppressing the oxidation of carbon. ${ }^{5)}$ The theoretical density of $\mathrm{Al}_{8} \mathrm{~B}_{4} \mathrm{C}_{7}$ is relatively low $\left.\left(2.69 \mathrm{~g} / \mathrm{cm}^{3}\right)^{6}\right)$ compared to other complex carbides, such as $\mathrm{AlTi}_{2} \mathrm{C}\left(4.11 \mathrm{~g} / \mathrm{cm}^{3}\right)^{7)}$ and $\mathrm{AlZrC}_{2}(5.12 \mathrm{~g} /$ $\left.\mathrm{cm}^{3}\right){ }^{8)}$ so $\mathrm{Al}_{8} \mathrm{~B}_{4} \mathrm{C}_{7}$ is expected to be useful as a high temperature construction material. Hence, mechanical properties are an important consideration. However, no investigation of the mechanical properties of dense $\mathrm{Al}_{8} \mathrm{~B}_{4} \mathrm{C}_{7}$ bodies has been reported to date.

In this study, the fabrication and mechanical properties of dense $\mathrm{Al}_{8} \mathrm{~B}_{4} \mathrm{C}_{7}$ bodies were investigated. First, $\mathrm{Al}_{8} \mathrm{~B}_{4} \mathrm{C}_{7}$ was fabricated from a mixed powder consisting of aluminum, boron carbide, and graphite. Next, dense $\mathrm{Al}_{8} \mathrm{~B}_{4} \mathrm{C}_{7}$ bodies were fabricated using a PECS technique, and the mechanical properties of the bodies were examined. Since this material is of interest for use as a high temperature construction material, the bending strength during heating was also measured. Finally, the mechanical properties of $\mathrm{Al}_{8} \mathrm{~B}_{4} \mathrm{C}_{7}$ were compared to those of other complex carbides, examining the feasibility of use as a construction material at high temperatures.

\section{Experimental procedure}

Reagent-grade aluminum powder (Kojundo Chemical Lab. Co., Ltd., purity: $99.9 \%$, grain size: $3 \mu \mathrm{m}$ ), $\mathrm{B}_{4} \mathrm{C}$ (Kojundo Chemical Lab. Co., Ltd., purity: 99.9\%, grain size: $5 \mu \mathrm{m}$ ), and graphite powder (Kojundo Chemical Lab. Co., Ltd., purity: 99.7\%, grain size: $5 \mu \mathrm{m}$ ) were used as starting materials. The powders were mixed with the ratio $\mathrm{Al}: \mathrm{B}_{4} \mathrm{C}: \mathrm{C}=8: 1: 6$ (molar ratio) to prepare the starting mixture. To fabricate $\mathrm{Al}_{8} \mathrm{~B}_{4} \mathrm{C}_{7}$, the starting mixture was uniaxially pressed at $30 \mathrm{MPa}$ to form a $20 \times 20 \times 10-\mathrm{mm}$ green compact, and then heated at $1550-1700^{\circ} \mathrm{C}$ for $1 \mathrm{~h}$ in $\mathrm{Ar}$. The synthesized $\mathrm{Al}_{8} \mathrm{~B}_{4} \mathrm{C}_{7}$ was ground in a ball mill with $10-\mathrm{mm}$ alumina balls for $24 \mathrm{~h}$, then sieved to under $40 \mu \mathrm{m}$ grain size. Subsequently, the $\mathrm{Al}_{8} \mathrm{~B}_{4} \mathrm{C}_{7}$ powder was placed into PECS equipment (SPS-525S: Sumitomo Sekitan Kogyo, Co., Ltd.) with carbon die and punches, and heated at $1650^{\circ} \mathrm{C}$ for 10 min under an applied pressure of $60 \mathrm{MPa}$ in vacuum. The heating rate was $50^{\circ} \mathrm{C} / \mathrm{min}$, and after heating the electric current was turned off.

The crystal phases of the synthesized samples were analyzed using an X-ray diffraction (XRD) equipment (XD-D1: Shimadzu Co., Ltd.). The bulk density of the sintered sample was measured by the Archimedean method and its intrinsic density was examined by pycnometer. The relative density of the sintered sample was calculated from these two values. To investigate mechanical properties, $2 \times 2 \times 10$-mm bar specimens were cut from the sintered samples, and three-point bending strength (fracture strength: AGS-5KND, Shimadzu Co., Ltd.) was measured. The fracture toughness was also examined using the same equipment (AGS-5KND, Shimadzu Co., Ltd.) and the SEVNB (Single Edge V-notched Beam) method. The Vickers hardness was evaluated using a hardness tester (AKV-A, Akashi Seisakusho, Co., Ltd.). The bending strength during heating was measured using different equipment (INSTRON 5582, INSTRON Co., Ltd.) from room temperature up to $1200^{\circ} \mathrm{C}$. Three to five specimens were used for the evaluation of each mechanical property. The micro- 
structures of the fracture surfaces of the sintered samples were observed by scanning electron microscopy (SEM; JSM-6300LV, JEOL Co., Ltd.). Polished, chemically etched surfaces of some samples were observed in order to examine the grain size. Polished samples were immersed in a Murakami reagent solution consisting of potassium hexacyanoferrate(II) and potassium hydroxide at $80-90^{\circ} \mathrm{C}$ for several hours. Average grain size was calculated using 15-20 grains per sample.

\section{Results and discussion}

\subsection{Synthesis and densification}

Figure 1 shows XRD patterns of the samples after heating the compacted starting powder mixture of $\mathrm{Al}: \mathrm{B}_{4} \mathrm{C}: \mathrm{C}=8: 1: 6$ at $1550-1700^{\circ} \mathrm{C}$ for $1 \mathrm{~h}$ in Ar. After heating to $1550^{\circ} \mathrm{C}$, diffraction peaks corresponding to $\mathrm{Al}_{4} \mathrm{C}_{3}$ were detected in the sample, but were very weak. On the other hand, pure $\mathrm{Al}_{8} \mathrm{~B}_{4} \mathrm{C}_{7}$ was formed after heating to over $1600^{\circ} \mathrm{C}$. Therefore, in this work, the heating temperature for synthesis of $\mathrm{Al}_{8} \mathrm{~B}_{4} \mathrm{C}_{7}$ was defined as $1600^{\circ} \mathrm{C}$. After synthesis, the $\mathrm{Al}_{8} \mathrm{~B}_{4} \mathrm{C}_{7}$ was ground by ball milling for $24 \mathrm{~h}$ and passed through a $40-\mu \mathrm{m}$ sieve, resulting in a powder with $<40 \mu \mathrm{m}$ grain size. Subsequently, a dense $\mathrm{Al}_{8} \mathrm{~B}_{4} \mathrm{C}_{7}$ body was fabricated from the ground powder using a PECS technique. Figures 2 and $\mathbf{3}$ show the change of relative density and SEM photographs of the fracture surfaces of sintered $\mathrm{Al}_{8} \mathrm{~B}_{4} \mathrm{C}_{7}$ bodies

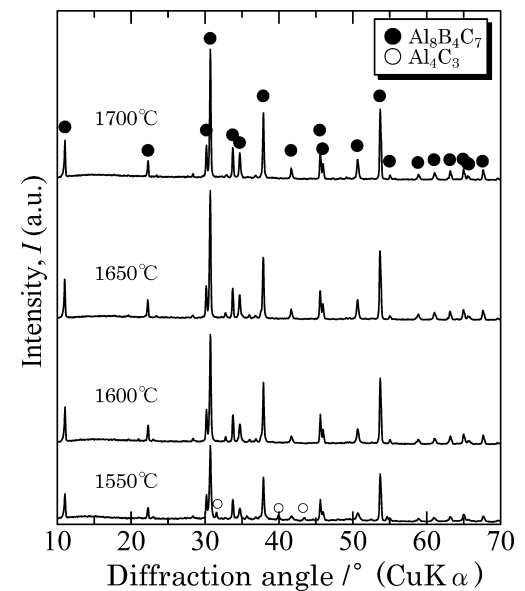

Fig. 1. XRD patterns of samples after heating the mixed starting powder compact consisting of $\mathrm{Al}: \mathrm{B}_{4} \mathrm{C}: \mathrm{C}=8: 1: 6$ (molar ratio) at 1550$1700^{\circ} \mathrm{C}$ for $1 \mathrm{~h}$ in $\mathrm{Ar}$.

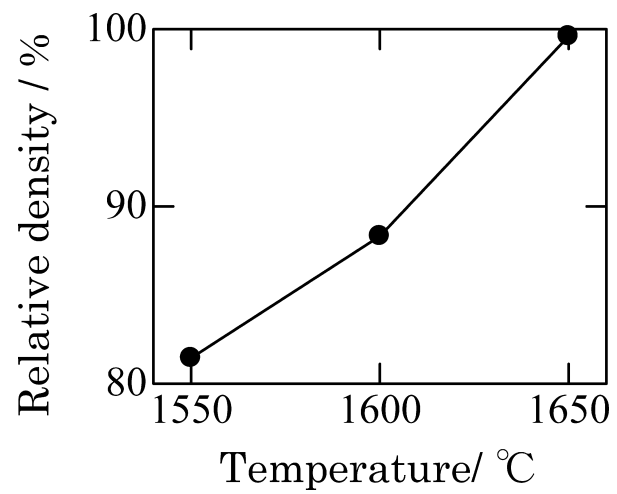

Fig. 2. Change in relative density of the sintered $\mathrm{Al}_{8} \mathrm{~B}_{4} \mathrm{C}_{7}$ body after heating at $1550-16500^{\circ} \mathrm{C}$ for $10 \mathrm{~min}$ with an applied pressure of $60 \mathrm{MPa}$ using a PECS technique. after sintering at $1550-1650^{\circ} \mathrm{C}$ for 10 min using a PECS technique. After heating to $1550^{\circ} \mathrm{C}$, the relative density was $81.5 \%$. This low relative density was a result of high porosity. The relative density increased with increasing temperature, finally reaching $99.6 \%$ at $1650^{\circ} \mathrm{C}$. In SEM micrographs of the dense body, micro-pores were not observed, and individual grains were not distinguishable.

\subsection{Mechanical properties}

Figure 4 shows that, for sintered $\mathrm{Al}_{8} \mathrm{~B}_{4} \mathrm{C}_{7}$ bodies, the Vickers hardness increases with increasing fabrication temperature. As the relative density of the $\mathrm{Al}_{8} \mathrm{~B}_{4} \mathrm{C}_{7}$ body also increases with increasing temperature, the increase in Vickers hardness was thought to be caused by increased density. The Vickers hardness of the $\mathrm{Al}_{8} \mathrm{~B}_{4} \mathrm{C}_{7}$ body fabricated at $1650^{\circ} \mathrm{C}$ with $99.6 \%$ relative density was $15.2 \mathrm{GPa}$. This value was similar to those of the other complex carbides $\mathrm{Al}_{4} \mathrm{SiC}_{4}{ }^{9)}$ and $\mathrm{AlZrC}_{2}{ }^{8)}$ However, compared to the commonly-used carbide, $\mathrm{SiC}(25.0 \mathrm{GPa}),{ }^{10)}$ the Vickers hardness of the $\mathrm{Al}_{8} \mathrm{~B}_{4} \mathrm{C}_{7}$ body was relatively low. The fracture toughness of the $\mathrm{Al}_{8} \mathrm{~B}_{4} \mathrm{C}_{7}$ body was also examined, and Fig. 5 depicts fracture toughness vs. fabrication temperature.
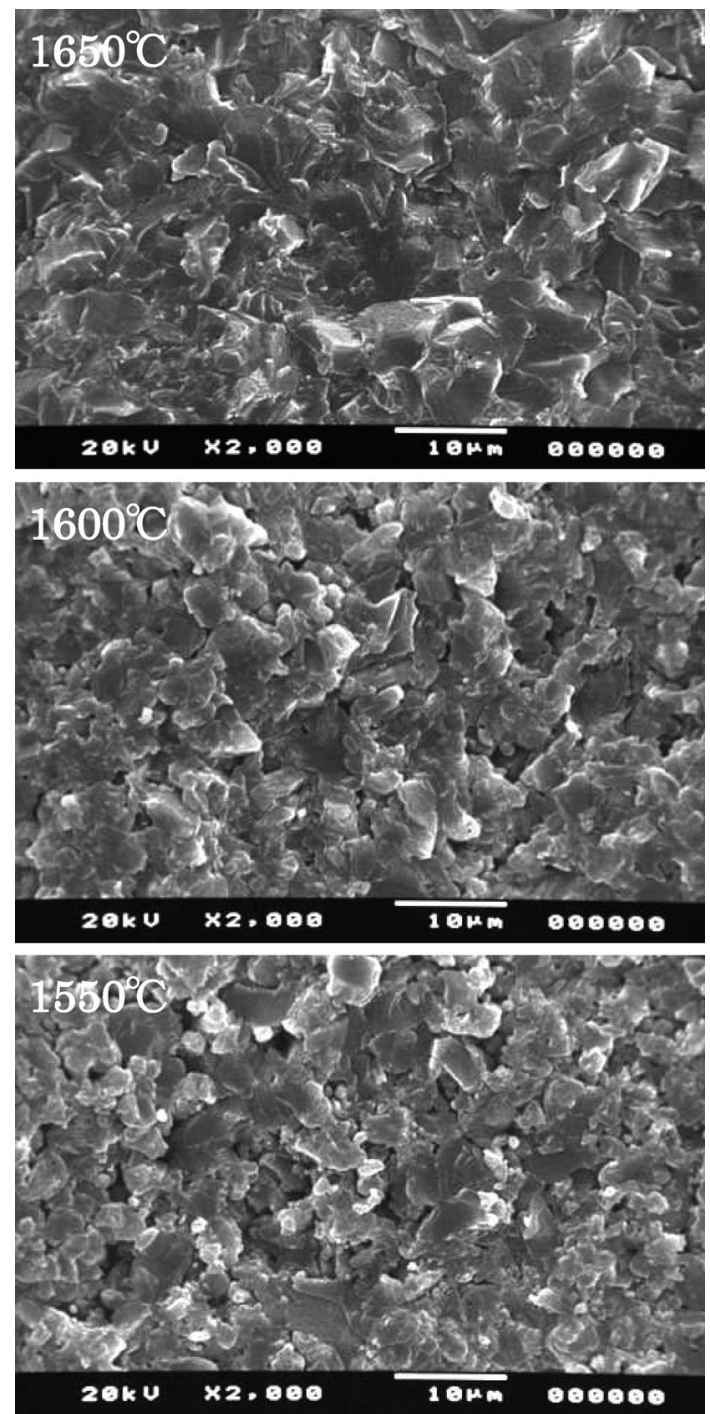

Fig. 3. SEM photographs of the fracture surfaces of $\mathrm{Al}_{8} \mathrm{~B}_{4} \mathrm{C}_{7}$ bodies fabricated at $1550-1650^{\circ} \mathrm{C}$ for $10 \mathrm{~min}$. 


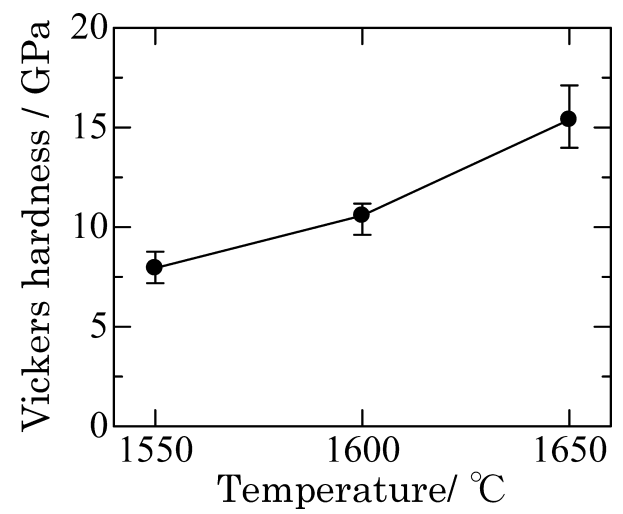

Fig. 4. Change in Vickers hardness of sintered $\mathrm{Al}_{8} \mathrm{~B}_{4} \mathrm{C}_{7}$ bodies fabricated at $1550-1650^{\circ} \mathrm{C}$ using a PECS technique.

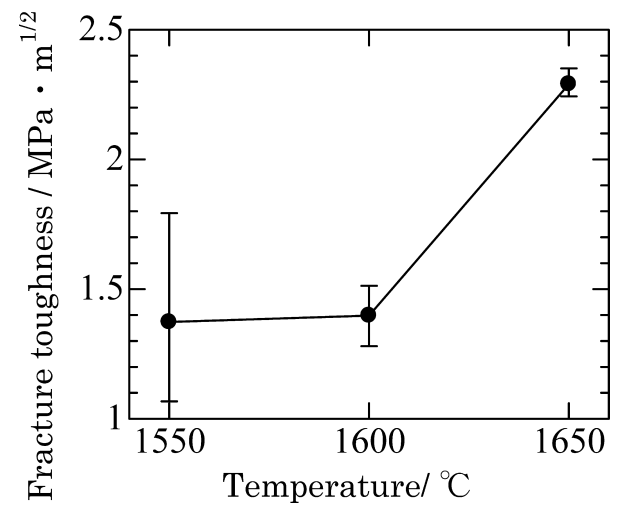

Fig. 5. Change in fracture toughness of $\mathrm{Al}_{8} \mathrm{~B}_{4} \mathrm{C}_{7}$ bodies fabricated at $1550-1650^{\circ} \mathrm{C}$ using a PECS technique.

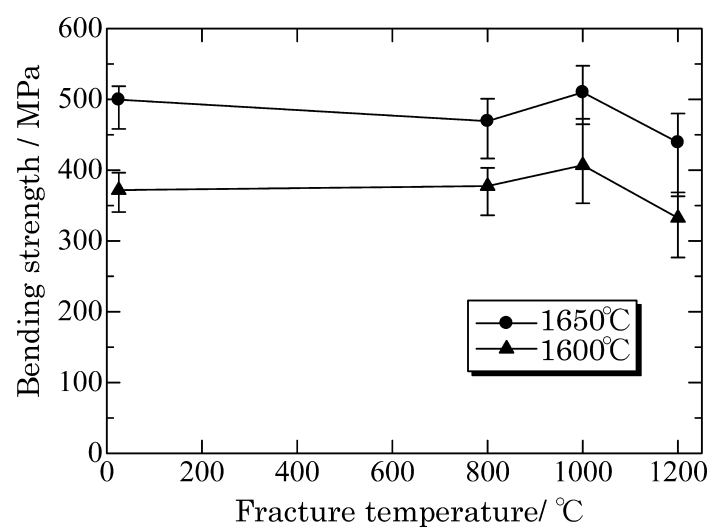

Fig. 6. Changes in bending strength of $\mathrm{Al}_{8} \mathrm{~B}_{4} \mathrm{C}_{7}$ bodies fabricated at 1600 and $1650^{\circ} \mathrm{C}$ measured at room temperature, 800, 1000, and $1200^{\circ} \mathrm{C}$.

$\mathrm{Al}_{8} \mathrm{~B}_{4} \mathrm{C}_{7}$ bodies fabricated at $1550^{\circ} \mathrm{C}$ and $1600^{\circ} \mathrm{C}$ had a fracture toughness of $1.4 \mathrm{MPa} \cdot \mathrm{m}^{1 / 2}$, while those fabricated at $1650^{\circ} \mathrm{C}$ had a fracture toughness of $2.3 \mathrm{MPa} \cdot \mathrm{m}^{1 / 2}$. This increase will be discussed as related to microstructural changes in the next section.

The bending strength of $\mathrm{Al}_{8} \mathrm{~B}_{4} \mathrm{C}_{7}$ bodies at both room temperature and high temperatures was also examined. Figure 6 shows the bending strength of samples fabricated at 1600 and $1650^{\circ} \mathrm{C}$ measured at room temperature, 800,1000 , and $1200^{\circ} \mathrm{C}$. At room temperature, the bending strength and other mechanical proper- ties were higher for $\mathrm{Al}_{8} \mathrm{~B}_{4} \mathrm{C}_{7}$ bodies fabricated at $1650^{\circ} \mathrm{C}$ than for those fabricated at $1600^{\circ} \mathrm{C}$. This increase in bending strength is thought to be caused by the higher relative density of the body when fabricated at the higher temperature. At room temperature, the bending strength of samples fabricated at $1650^{\circ} \mathrm{C}$ averaged $500 \mathrm{MPa}$. The bending strength of the $\mathrm{Al}_{8} \mathrm{~B}_{4} \mathrm{C}_{7}$ body during heating showed a similar behavior between the two samples, and the bending strength of the body fabricated at $1650^{\circ} \mathrm{C}$ was higher than that of the body fabricated at $1600^{\circ} \mathrm{C}$ at all measurement temperatures. Interestingly, when the $\mathrm{Al}_{8} \mathrm{~B}_{4} \mathrm{C}_{7}$ body fabricated at $1650^{\circ} \mathrm{C}$ was heated to $1000^{\circ} \mathrm{C}$, its bending strength increased slightly compared to that measured at room temperature, reaching $510 \mathrm{MPa}$. However, at $1200^{\circ} \mathrm{C}$, the bending strength of both samples slightly decreased, dropping to $440 \mathrm{MPa}$ in the case of the $\mathrm{Al}_{8} \mathrm{~B}_{4} \mathrm{C}_{7}$ body fabricated at $1650^{\circ} \mathrm{C}$. It was previously reported that the bending strength of $\mathrm{Al}_{4} \mathrm{SiC}_{4}$ increased from 300 to $450 \mathrm{MPa}$ when samples were heated from room temperature to $1300^{\circ} \mathrm{C}^{11)}$ This improvement in bending strength was thought to be caused by the onset of viscous flow of silicate glass on the surface of the $\mathrm{Al}_{4} \mathrm{SiC}_{4}$ specimen, which tended to heal microcracks which would otherwise serve as origins of fracture. In the case of $\mathrm{Al}_{8} \mathrm{~B}_{4} \mathrm{C}_{7}$ bodies, a similar viscous flow of a borate glass phase on the sample surface was thought to occur during heating. This would heal surface micro-cracks in the same manner as the silicate glass flow did on $\mathrm{Al}_{4} \mathrm{SiC}_{4}$ samples. As a result, at up to $1000^{\circ} \mathrm{C}$, the bending strength was slightly higher than at room temperature. Furthermore, the fracture strength of the dense $\mathrm{Al}_{8} \mathrm{~B}_{4} \mathrm{C}_{7}$ body maintained at elevated temperatures and increased slightly at $1000^{\circ} \mathrm{C}$ was thought to be caused by that no additive was added into the $\mathrm{Al}_{8} \mathrm{~B}_{4} \mathrm{C}_{7}$ compact for a sintering in spite of its lower sinterability. That is, some glass phases which lead to decrease the fracture strength seemed not to form at grain boundaries at elevated temperatures. Actually, according to the SEM photograph of the fractured surface of the dense $\mathrm{Al}_{8} \mathrm{~B}_{4} \mathrm{C}_{7}$ body fabricated at $1650^{\circ} \mathrm{C}$ during heating at $1000^{\circ} \mathrm{C}$, the fracture mode was a transgranular type which suggested no formation of glass phases at grain boundaries and maintained from that mode of the dense body at room temperature, as shown in Fig. 3 (omitted here for brevity). In addition, some anisotropic grains with aspect ratio of 2 to 4 were observed, as shown in Fig. 7. So there must exist some interfacial stresses between thermal expansion coefficients in different directions. Such maintained and/or increased strength till $1000^{\circ} \mathrm{C}$ was also thought to be the release of the residual thermal stress. At $1200^{\circ} \mathrm{C}$, this micro-crack healing mechanism no longer functions, because the viscosity of the flowing borate glass becomes too low to result in any improvement in bending strength. Furthermore, the lattice vibration became strong to decrease the fracture energy, thus fracture strength would tend to decrease at $1200^{\circ} \mathrm{C}$. However, since the $\mathrm{Al}_{8} \mathrm{~B}_{4} \mathrm{C}_{7}$ body maintained a bending strength of $440 \mathrm{MPa}$ at $1200^{\circ} \mathrm{C}$, this material is strong enough to use as a high-temperature construction material.

\subsection{Microstructures}

Figure 7 shows SEM micrographs of the polished surfaces of $\mathrm{Al}_{8} \mathrm{~B}_{4} \mathrm{C}_{7}$ bodies fabricated at 1550,1600 and $1650^{\circ} \mathrm{C}$ after chemical etching. As seen in the figure, the grain size increased with increasing fabrication temperature. The grain cross-sections did not show a typical shape, so the grain size was defined as the longest measurable width. The average grain size of the $\mathrm{Al}_{8} \mathrm{~B}_{4} \mathrm{C}_{7}$ bodies fabricated at 1550,1600 and $1650^{\circ} \mathrm{C}$ was $4.5,6.0$ and 9.3 $\mu \mathrm{m}$, respectively. The grain growth from 1600 at $1650^{\circ} \mathrm{C}$ was notable, and there is a possibility that the increase in fracture 

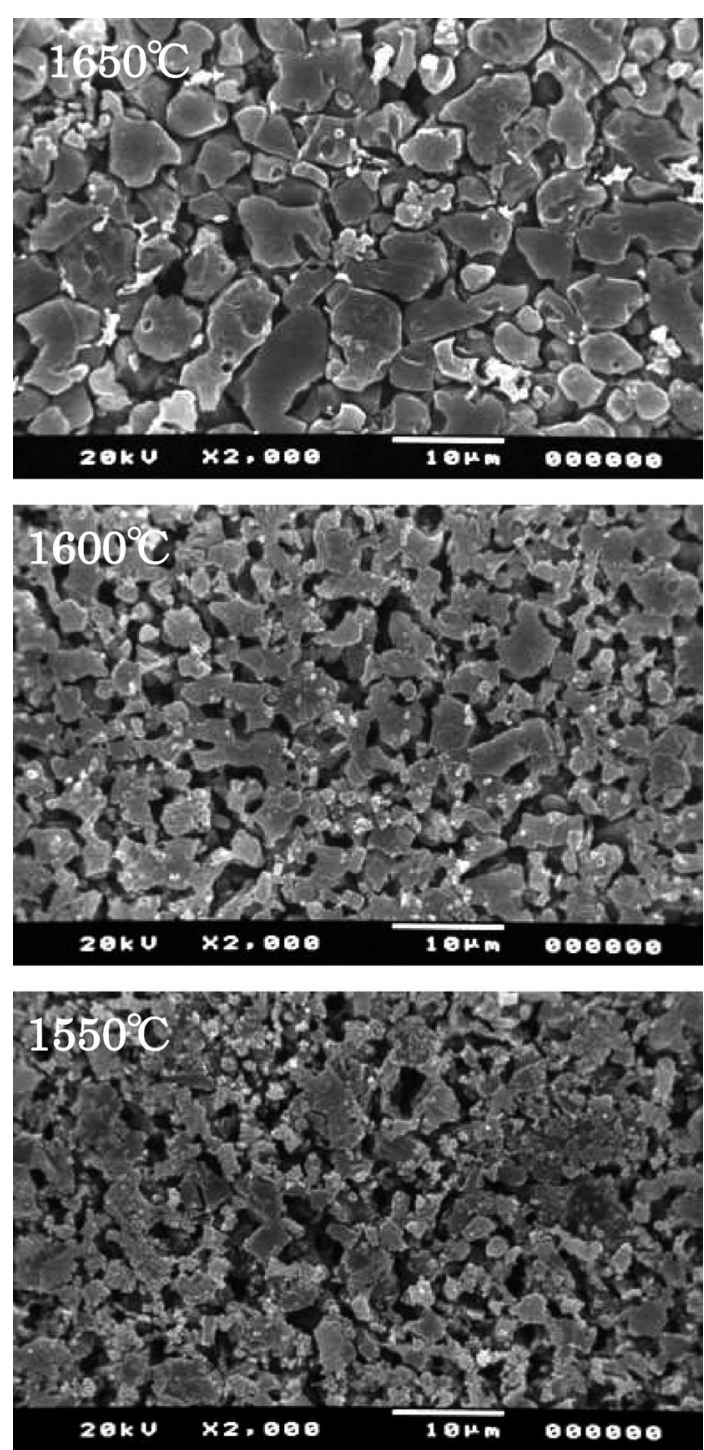

Fig. 7. SEM photographs of the polished surfaces of $\mathrm{Al}_{8} \mathrm{~B}_{4} \mathrm{C}_{7}$ bodies fabricated at 1550,1600 and $1650^{\circ} \mathrm{C}$ after chemical etching treatment.

toughness is caused by this grain growth, as shown in Fig. 5. On the contrary, the increase in bending strength with increasing fabrication temperature was thought to be caused by increased density, as mentioned previously. Although the increase in Vickers hardness with increasing fabrication temperature was also thought to be caused by increased density, the relationship between grain growth and Vickers hardness is unclear.

Finally, the formation of borate glass on the surface of $\mathrm{Al}_{8} \mathrm{~B}_{4} \mathrm{C}_{7}$ bodies during heating was confirmed. SEM observation of samples heated to $1000^{\circ} \mathrm{C}$ showed no distinguishable layer of borate glass on the surface of the $\mathrm{Al}_{8} \mathrm{~B}_{4} \mathrm{C}_{7}$ body, so this micrograph was omitted. It was considered that the thickness of the borate glass layer was very thin, only several micrometers, but was able to heal micro-cracks within the layer and improve the sample strength. Figure 8 shows an SEM micrograph of the surface of the $\mathrm{Al}_{8} \mathrm{~B}_{4} \mathrm{C}_{7}$ body fabricated at $1600^{\circ} \mathrm{C}$, after testing its bending strength at $1200^{\circ} \mathrm{C}$. In this figure, a reactant layer, which seemed to be the borate glass, approximately $10 \mu \mathrm{m}$ thick was

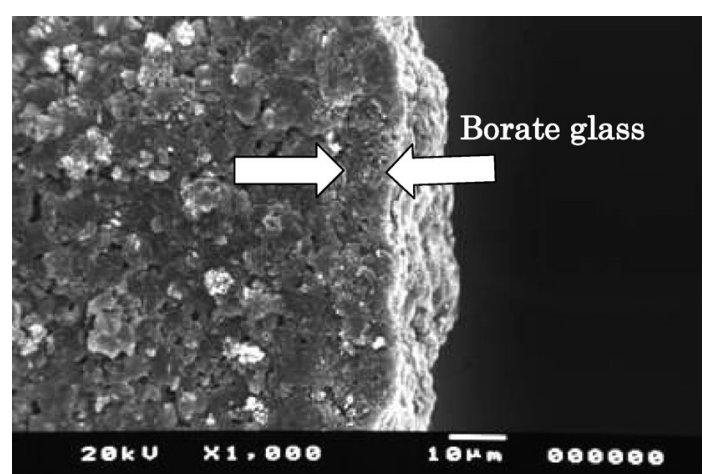

Fig. 8. SEM photograph of the surface of an $\mathrm{Al}_{8} \mathrm{~B}_{4} \mathrm{C}_{7}$ body fabricated at $1600^{\circ} \mathrm{C}$ after bending strength measurement at $1200^{\circ} \mathrm{C}$.

clearly seen. However, the viscosity of this borate glass layer could be lower at $1200^{\circ} \mathrm{C}$ than at $1000^{\circ} \mathrm{C}$, so that the glass layer could no longer effectively heal micro-cracks, resulting in a decrease in bending strength, as mentioned previously.

\section{Summary}

Aluminum boron carbide $\left(\mathrm{Al}_{8} \mathrm{~B}_{4} \mathrm{C}_{7}\right)$ was synthesized by solid phase reaction from aluminum, boron carbide $\left(\mathrm{B}_{4} \mathrm{C}\right)$, and graphite powders in an 8:1:6 molar ratio at $1600^{\circ} \mathrm{C}$ for $1 \mathrm{~h}$ in Ar. A dense $\mathrm{Al}_{8} \mathrm{~B}_{4} \mathrm{C}_{7}$ body with a $99.6 \%$ relative density was fabricated using a PECS technique at $1650^{\circ} \mathrm{C}$ for 10 min with an applied pressure of $60 \mathrm{MPa}$. The Vickers hardness, fracture toughness, and bending strength of bodies fabricated at $1650^{\circ} \mathrm{C}$ were 500 $\mathrm{MPa}, 15.2 \mathrm{GPa}$, and 2.3 $\mathrm{MPa} \cdot \mathrm{m}^{1 / 2}$, respectively. The bending strength of the dense $\mathrm{Al}_{8} \mathrm{~B}_{4} \mathrm{C}_{7}$ body heated to $1000^{\circ} \mathrm{C}$ increased slightly to $510 \mathrm{MPa}$, but after heating to $1200^{\circ} \mathrm{C}$ the bending strength decreased to $440 \mathrm{MPa}$. Since $440 \mathrm{MPa}$ is still a relatively high bending strength, $\mathrm{Al}_{8} \mathrm{~B}_{4} \mathrm{C}_{7}$ should be considered a useful construction material at high temperatures.

\section{References}

1) J. C. Viala, J. Bouix, G. Gonzalez and C. Esnouf, J. Mater. Sci., 32, 4559-4573 (1997).

2) Z. Inoue, H. Tanaka and Y. Inomata, J. Mater. Sci., 15, 30363040 (1980).

3) A. I. Kharalamov and S. V. Loichenk, AIP (American Institute of Physics) Conference Proceedings, 231, 94-103 (1991).

4) T. Wang and A. Yamaguchi, J. Ceram. Soc. Japan, 108, 375380 (2000).

5) A. Yamaguchi, Y. Nakano and T. Wang, Canadian Metallurgical Quarterly, 39, 381-386 (2000).

6) T. Wang and A. Yamaguchi, J. Mater. Sci. Lett., 19, 10451046 (2000).

7) S. Hashimoto, M. Takeuchi, K. Inoue, S. Honda, H. Awaji, K. Fukuda and S. Zhang, Mater. Lett., 62, 1480-1483 (2008).

8) U. L.-Adisorn, S.-M. Choi, N. Tera, M. Takeuchi, S. Hashimoto, S. Honda, H. Awaji, K. Hayakawa and A. Yamaguchi, $J$. Ceram. Soc. Japan, 113, 188-190 (2005).

9) S. Hashimoto, T. Asano, K. Inoue, S. Honda, Y. Iwamoto, K. Fukuda and S. Zhang, Taikabutsu Overseas (2009) in press.

10) T. Yamaguchi and H. Yanagida, "Engineering Ceramics," Gihodo Shuppan (1988) pp. 16-21 [in Japanese].

11) G. W. Wen and X. X. Huang, J. Eur. Ceram. Soc., 26, 12811286 (2006). 